\title{
DUS Characterization for Germplasm of Rice
}

\author{
B. Kalyan ${ }^{1 *}$, K.V. Radha Krishna ${ }^{1}$ and L.V. Subba Rao ${ }^{2}$ \\ ${ }^{1}$ Department of Genetics and Plant Breeding, College of Agriculture, PJTSAU, \\ Hyderabad-30, Telangana, India \\ ${ }^{2}$ Directorate of Rice Research, Rajendranagar, Hyderabad-30, Telangana, India \\ *Corresponding author
}

\begin{tabular}{|c|c|}
\hline & A B S T R A C T \\
\hline Keywords & \multirow{4}{*}{$\begin{array}{l}\text { For the establishment of the distinctness among thirty-five landraces of } \\
\text { rice, twenty nine characters were used. Characterization of thirty-five } \\
\text { landraces of rice was done using twenty nine agro-morphological traits } \\
\text { following Distinctiveness, Uniformity and Stability test (DUS) during } \\
\text { kharif season of } 2014 \text { at the DRR farm, ICRISAT campus. Out of thirty- } \\
\text { five varieties studied, twenty-two were found to be distinctive on the basis } \\
\text { of twenty nine essential characters. This study will be useful for breeders, } \\
\text { researchers and farmers to identify and choose the restoration and } \\
\text { conservation of beneficial genes for crop improvement and also to seek } \\
\text { protection under Protection of Plant Varieties and Farmer's Rights Act. }\end{array}$} \\
\hline $\begin{array}{l}\text { DUS test, Land } \\
\text { races, } \\
\text { Characterization, } \\
\text { PPV \& FR Act. }\end{array}$ & \\
\hline Article Info & \\
\hline $\begin{array}{l}\text { Accepted: } \\
\text { 28 September } 2017 \\
\text { Available Online: } \\
\text { 10 October } 2017\end{array}$ & \\
\hline
\end{tabular}

\section{Introduction}

Rice is the world's most important food crop and a primary food source for more than one third of world's population (1). The essence of plant breeding lies in the creation of genetic variation which is a prerequisite for any improvement in crop. The development of one or more varieties depends on the final selection of superior plants by the plant breeder who uses several techniques to create the genetic variation and to select from within that variation (2). India has a rich and wide range of genetic wealth of rice. It has been estimated from various surveys that nearly 50,000 of rice is still being grown in the country (3). With the introduction of high yielding varieties and new technologies become a great threat to the $\backslash$ security of the age-old practice of growing traditional varieties and landraces which may have immense potential for different important traits (4). As the existing UPOV models of plant variety protection were not suitable for Indian requirements, the Government of India enacted our own legislation on the "Protection of Plant Varieties and Farmers Act" (PPV\&FRA) in 2001 for providing protection to plant varieties based on distinctiveness, uniformity and stability (DUS) test apart from novelty. which is a unique and model act which gives equal importance to the farmers and breeders and treats them as partners in their efforts for sustainable food security(5). Thus the process of variety identification includes several steps were identification of a 
variety, Confirmation of the variety, Distinctness of the variety from all other in common knowledge, Purity of the variety and Characterization of the variety which enumerates its full descriptors. The concept of distinctness, uniformity and stability are thus fundamental to the characterization of a variety as a unique creation. Registration is allowed for three types of plant varieties new varieties bred by breeders, extant varieties and farmer's varieties subject to their fulfilling the conditions of Distinctness, Uniformity and Stability and Novelty in case of breeder's variety. The uniqueness of a particular variety is to be established by the test called DUS. The first step to implement our PPV\&FR Act provisions is formulation of National Test Guidelines for conducting DUS tests. In this context, an attempt was made to characterize a set of thirty-five genotypes of rice germplasm for different morphological and agronomic traits and identify the variability available in the collection.

\section{Materials and Methods}

Thirty five farmer's varieties of rice (Table 1) were grown in a randomized complete block design with three replications at the IIRR farm, ICRISAT campus, Situated at $17.53^{\circ} \mathrm{N}$ latitude, $78.27^{\circ} \mathrm{E}$ longitude and altitude of $545 \mathrm{~m}$ above mean sea level. The material was grown in a complete randomized block design with five checks in three replications during Kharif 2014. Each entry was sown in three rows of $2 \mathrm{~m}$ length at spacing of $20 \mathrm{~cm}$ between rows and $15 \mathrm{~cm}$ between plants.

Crop was raised following recommended package of practices. Observations were recorded on five randomly chosen plants of each genotype per replication for twenty-nine morphological and agronomical traits which are visuallyl assessed characteristics were observed according to the National Test Guidelines for DUS test in rice which was developed by Indian Institute of Rice
Research, Rajendranagar, Hyderabad (7). The observation of various characteristics was recorded at different stages of growth with appropriate procedures as per the DUS test guidelines of PPV \& FR Act, 2001. Like UPOV, in PPV and FR Act, a variety must fulfil the criteria of Distinctiveness, Uniformity, Stability and novelty (if new) so as to get protection under this act (8). The traits studied were Basal leaf sheath colour, Leaf pubescence of blade surface, Leaf auricles, Leaf anthocyanin colouration of auricles, Leaf shape of ligule, Leaf colour of ligule, Time of heading $(50 \%$ of plants with panicles), Flag leaf attitude of blade (early observation), Spikelet density of pubescence of lemma, Lemma anthocyanin colouration of apex, Spikelet colour of stigma, Stem length (excluding panicle; excluding floating rice), Stem anthocyanin colouration of nodes, Panicle length of main axis, Flag lea attitude of blade (late observation), Panicle curvature of main axis, Spikelet colour of tip of lemma, Panicle awns, Panicle colour of awns (late observation), Panicle distribution of awns, Panicle attitude of branches, Panicle exsertion, Sterile lemma colour, Decorticated grain length, Decorticated grain width, Decorticated grain shape (in lateral view), Decorticated grain colour, Endosperm content of amylase and Decorticated grain aroma

\section{Results and Discussion}

To establish distinctiveness among rice cultivars, 29 essential characters have been used. Qualitative characters are considered as morphological markers in the identification of landraces of rice, because they are less influenced by environmental changes. Regarding leaf characteristics (Table 3), intensity of green colour of leaf sheath was dark green in 23 genotypes and 12 lines are with purple variation out of the total 35 genotypes and 20 lines with strong and 11 with medium pubescence on leaf blade while 4 lines have no pubescence. 
Table.1 List of genotypes and the place of collection

\begin{tabular}{|c|c|c|c|c|c|}
\hline S.No & Name of the genotype & Place of collection & S.No & Name of the genotype & Place of collection \\
\hline 1 & IC-449549X & DRR, Hyderabad & 19 & IC-75913 & DRR, Hyderabad \\
\hline 2 & IC-449560X & DRR, Hyderabad & 20 & IC-75920 & DRR, Hyderabad \\
\hline 3 & IC-75758 & DRR, Hyderabad & 21 & IC-216693 & DRR, Hyderabad \\
\hline 4 & IC-75738 & DRR, Hyderabad & 22 & IC-216736 & DRR, Hyderabad \\
\hline 5 & IC-75747 & DRR, Hyderabad & 23 & IC-216689 & DRR, Hyderabad \\
\hline 6 & IC-75756 & DRR, Hyderabad & 24 & IC-217783 & DRR, Hyderabad \\
\hline 7 & IC-75782 & DRR, Hyderabad & 25 & IC-217746 & DRR, Hyderabad \\
\hline 8 & IC-75789 & DRR, Hyderabad & 26 & IC-217747 & DRR, Hyderabad \\
\hline 9 & IC-75773 & DRR, Hyderabad & 27 & IC-217748 & DRR, Hyderabad \\
\hline 10 & IC-75783 & DRR, Hyderabad & 28 & IC-217760 & DRR, Hyderabad \\
\hline 11 & IC-75786 & DRR, Hyderabad & 29 & IC-217771 & DRR, Hyderabad \\
\hline 12 & IC-75772 & DRR, Hyderabad & 30 & IC-217749 & DRR, Hyderabad \\
\hline 13 & IC-75775 & DRR, Hyderabad & 31 & IC-217750 & DRR, Hyderabad \\
\hline 14 & IC-75779 & DRR, Hyderabad & 32 & IC-217758 & DRR, Hyderabad \\
\hline 15 & IC-75843 & DRR, Hyderabad & 33 & IC-217762 & DRR, Hyderabad \\
\hline 16 & IC-75864 & DRR, Hyderabad & 34 & IC-217769 & DRR, Hyderabad \\
\hline 17 & IC-75855 & DRR, Hyderabad & 35 & IC-217776 & DRR, Hyderabad \\
\hline 18 & IC-75849 & DRR, Hyderabad & & & \\
\hline
\end{tabular}


Table.2 Essential characters along with descriptor

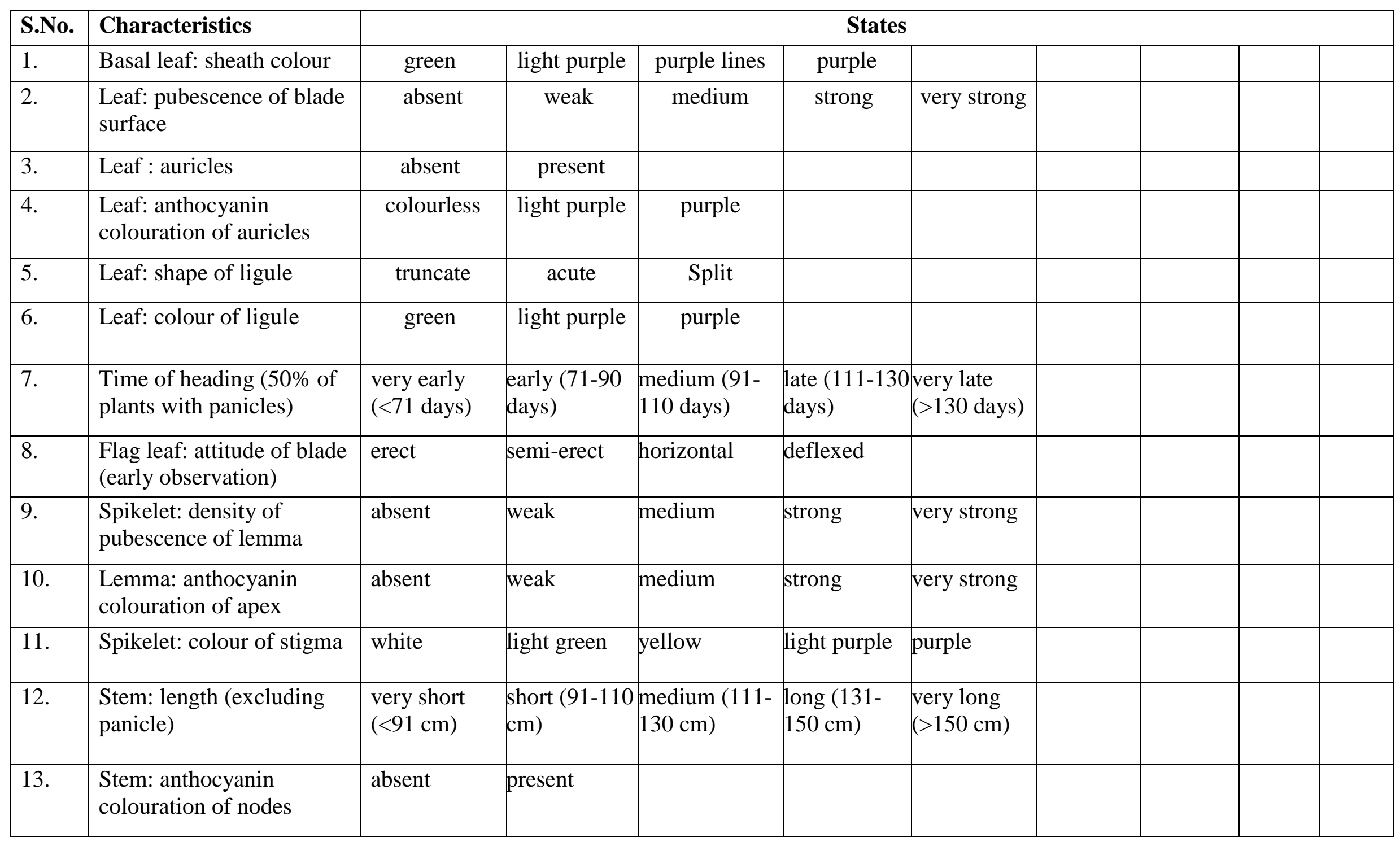




\begin{tabular}{|c|c|c|c|c|c|c|c|c|c|c|}
\hline 14. & $\begin{array}{l}\text { Panicle: length of main } \\
\text { axis }\end{array}$ & $\begin{array}{l}\text { very short } \\
(<16 \mathrm{~cm})\end{array}$ & $\begin{array}{l}\text { short }(16-20 \\
\mathrm{cm})\end{array}$ & $\begin{array}{l}\text { medium }(21- \\
25 \mathrm{~cm})\end{array}$ & $\begin{array}{l}\text { long }(26-30 \\
\mathrm{cm})\end{array}$ & $\begin{array}{l}\text { very long } \\
(>30 \mathrm{~cm})\end{array}$ & & & & \\
\hline 15. & $\begin{array}{l}\text { Flag leaf: attitude of blade } \\
\text { (late observation) }\end{array}$ & erect & semi-erect & horizontal & Deflexed & & & & & \\
\hline 16. & $\begin{array}{l}\text { Panicle: curvature of main } \\
\text { axis }\end{array}$ & straight & semi-straight & drooping & deflexed & & & & & \\
\hline 17. & $\begin{array}{l}\text { Spikelet : colour of tip of } \\
\text { lemma }\end{array}$ & White & Yellowish & Brown & Red, & Purple & Black & & & \\
\hline 18. & Panicle : awns & Absent & Present & & & & & & & \\
\hline 19. & $\begin{array}{l}\text { Panicle: colour of awns } \\
\text { (late observation) }\end{array}$ & $\begin{array}{l}\text { Yellowish } \\
\text { white }\end{array}$ & $\begin{array}{l}\text { Yellowish } \\
\text { brown }\end{array}$ & Brown & $\begin{array}{l}\text { Reddish } \\
\text { brown }\end{array}$ & Ligh t red & Red & $\begin{array}{l}\text { Light } \\
\text { purple }\end{array}$ & Purple & Black \\
\hline 20. & $\begin{array}{l}\text { Panicle: distribution of } \\
\text { awns }\end{array}$ & tip only & $\begin{array}{l}\text { upper half } \\
\text { only }\end{array}$ & whole length & & & & & & \\
\hline 21. & $\begin{array}{l}\text { Panicle: attitude of } \\
\text { branches }\end{array}$ & Erect & $\begin{array}{l}\text { Erect to } \\
\text { semi-erect }\end{array}$ & Semi-erect & $\begin{array}{l}\text { Semi-erect to } \\
\text { spreading }\end{array}$ & Spreading & & & & \\
\hline 22. & Panicle: exsertion & $\begin{array}{l}\text { Partly } \\
\text { exserted }\end{array}$ & $\begin{array}{l}\text { Exserted } \\
\text { well }\end{array}$ & Exserted & & & & & & \\
\hline 23. & Sterile lemma: colour & straw & gold & red & purple & & & & & \\
\hline 24. & $\begin{array}{l}\text { Decorticated grain: } \\
\text { length }\end{array}$ & very short & short & medium & long & very long & & & & \\
\hline 25. & Decorticated grain: width & $\begin{array}{l}\text { narrow }(<2.0 \\
\mathrm{mm})\end{array}$ & $\begin{array}{l}\text { medium }(2.0- \\
2.5 \mathrm{~mm})\end{array}$ & $\begin{array}{l}\text { broad }(>2.5 \\
\mathrm{mm})\end{array}$ & & & & & & \\
\hline 26. & Decorticated grain: shape & $\begin{array}{l}\text { short } \\
\text { slender }\end{array}$ & short bold & medium & long slender & long bold & extra long & & & \\
\hline 27. & Decorticated grain: colour & white & light brown & $\begin{array}{l}\text { variegated } \\
\text { brown }\end{array}$ & dark brown & light red & red & $\begin{array}{l}\text { variegated } \\
\text { purple }\end{array}$ & purple & $\begin{array}{l}\text { dark } \\
\text { purple }\end{array}$ \\
\hline 28. & $\begin{array}{l}\text { Endosperm: content of } \\
\text { amylase }\end{array}$ & $\begin{array}{l}\text { very low } \\
(<10 \%)\end{array}$ & low $(10-19 \%)$ & $\begin{array}{l}\text { medium(20- } \\
25 \%)\end{array}$ & $\begin{array}{l}\operatorname{high}(26- \\
30 \%)\end{array}$ & $\begin{array}{l}\text { very high } \\
(>30 \%)\end{array}$ & & & & \\
\hline 29. & Decorticated grain: aroma & absent & present & & & & & & & \\
\hline
\end{tabular}


Table.3 Characterization of the cultivars (total 35) as per DUS guidelines

\begin{tabular}{|c|c|c|c|c|c|c|c|c|c|c|c|c|c|c|c|c|c|c|c|c|c|c|c|c|c|c|c|c|c|c|}
\hline S.No & Cultivar & $\mathrm{A}$ & $\mathrm{b}$ & $\mathrm{c}$ & $\mathrm{d}$ & $\mathrm{e}$ & $\mathrm{f}$ & $\mathrm{g}$ & $\mathrm{h}$ & i & j & $\mathrm{k}$ & 1 & $\mathrm{~m}$ & $\mathrm{n}$ & o & $\mathrm{p}$ & $\mathrm{q}$ & $\mathrm{r}$ & $\mathrm{s}$ & $\mathrm{t}$ & $\mathrm{u}$ & $\mathrm{v}$ & $\mathrm{w}$ & $\mathrm{x}$ & $\mathrm{y}$ & $\mathrm{z}$ & aa & $a b$ & $\mathrm{ac}$ \\
\hline 1 & IC-449549X & 1 & 1 & 9 & 1 & 3 & 1 & 5 & 1 & 5 & 1 & 1 & 1 & 1 & 5 & 3 & 5 & 3 & 1 & - & - & 9 & 7 & 1 & 5 & 3 & 5 & 4 & 5 & 1 \\
\hline 2 & IC-449560X & 1 & 5 & 9 & 1 & 3 & 1 & 5 & 3 & 5 & 7 & 1 & 3 & 1 & 5 & 5 & 7 & 5 & 1 & - & - & 9 & 7 & 1 & 5 & 3 & 5 & 2 & 5 & 1 \\
\hline 3 & IC-75748 & 1 & 7 & 9 & 1 & 3 & 1 & 7 & 1 & 7 & 1 & 1 & 1 & 1 & 7 & 3 & 7 & 2 & 9 & 1 & 1 & 3 & 5 & 1 & 5 & 3 & 5 & 2 & 7 & 1 \\
\hline 4 & IC-75738 & 1 & 5 & 9 & 1 & 3 & 1 & 7 & 1 & 5 & 1 & 1 & 1 & 1 & 7 & 1 & 7 & 2 & 1 & - & - & 3 & 5 & 1 & 5 & 3 & 5 & 2 & 5 & 1 \\
\hline 5 & IC-75747 & 1 & 7 & 9 & 1 & 3 & 1 & 7 & 1 & 5 & 1 & 1 & 1 & 1 & 5 & 1 & 3 & 3 & 9 & 1 & 1 & 3 & 5 & 1 & 5 & 5 & 3 & 5 & 5 & 1 \\
\hline 6 & IC-75756 & 1 & 7 & 9 & 1 & 3 & 1 & 5 & 1 & 7 & 1 & 1 & 1 & 1 & 5 & 1 & 3 & 2 & 9 & 1 & 1 & 3 & 3 & 1 & 5 & 7 & 3 & 2 & 7 & 1 \\
\hline 7 & IC-75782 & 1 & 7 & 9 & 3 & 3 & 1 & 7 & 1 & 5 & 5 & 5 & 1 & 1 & 5 & 1 & 7 & 5 & 1 & - & - & 3 & 5 & 1 & 5 & 5 & 4 & 1 & 5 & 1 \\
\hline 8 & IC-75789 & 1 & 7 & 9 & 1 & 3 & 1 & 7 & 1 & 5 & 1 & 1 & 1 & 1 & 5 & 1 & 7 & 2 & 1 & 1 & 1 & 9 & 5 & 4 & 5 & 3 & 5 & 1 & 7 & 1 \\
\hline 9 & IC-75773 & 1 & 7 & 9 & 1 & 3 & 1 & 7 & 1 & 5 & 1 & 5 & 3 & 1 & 5 & 1 & 7 & 2 & 1 & - & - & 3 & 5 & 1 & 5 & 5 & 5 & 2 & 5 & 1 \\
\hline 10 & IC-75783 & 3 & 7 & 9 & 3 & 3 & 2 & 5 & 1 & 5 & 5 & 5 & 1 & 9 & 5 & 1 & 7 & 5 & 9 & 1 & 3 & 3 & 5 & 1 & 5 & 3 & 5 & 1 & 5 & 1 \\
\hline 11 & IC-75786 & 1 & 7 & 9 & 1 & 3 & 1 & 5 & 1 & 5 & 1 & 1 & 1 & 1 & 7 & 1 & 5 & 3 & 1 & - & - & 9 & 5 & 1 & 5 & 3 & 5 & 2 & 5 & 1 \\
\hline 12 & IC-75772 & 1 & 7 & 9 & 1 & 3 & 1 & 7 & 1 & 5 & 1 & 1 & 3 & 1 & 7 & 1 & 7 & 2 & 9 & 1 & 1 & 3 & 5 & 1 & 5 & 3 & 5 & 1 & 5 & 1 \\
\hline 13 & IC-75775 & 1 & 7 & 9 & 1 & 3 & 1 & 7 & 1 & 5 & 1 & 1 & 1 & 1 & 5 & 1 & 7 & 2 & 1 & - & - & 9 & 5 & 1 & 5 & 5 & 3 & 1 & 5 & 1 \\
\hline 14 & IC-75779 & 1 & 7 & 9 & 1 & 3 & 1 & 5 & 1 & 5 & 1 & 1 & 1 & 1 & 7 & 1 & 7 & 2 & 1 & - & - & 3 & 5 & 1 & 5 & 3 & 5 & 2 & 7 & 1 \\
\hline 15 & IC-75843 & 1 & 5 & 9 & 1 & 3 & 1 & 3 & 1 & 5 & 1 & 1 & 1 & 1 & 5 & 1 & 7 & 2 & 1 & - & - & 9 & 7 & 4 & 5 & 3 & 5 & 2 & 7 & 1 \\
\hline 16 & IC-75864 & 1 & 7 & 9 & 1 & 3 & 1 & 5 & 1 & 5 & 1 & 1 & 1 & 1 & 7 & 1 & 7 & 1 & 1 & - & - & 3 & 5 & 1 & 5 & 3 & 5 & 1 & 5 & 1 \\
\hline 17 & IC-75855 & 2 & 7 & 9 & 3 & 3 & 2 & 7 & 1 & 5 & 5 & 5 & 1 & 1 & 5 & 1 & 7 & 5 & 1 & - & - & 9 & 5 & 4 & 5 & 5 & 3 & 1 & 7 & 1 \\
\hline 18 & IC-75849 & 1 & 5 & 9 & 1 & 3 & 1 & 7 & 1 & 5 & 1 & 1 & 1 & 1 & 7 & 3 & 7 & 3 & 1 & - & - & 3 & 5 & 1 & 5 & 3 & 2 & 1 & 5 & 1 \\
\hline 19 & IC-75913 & 1 & 7 & 9 & 1 & 3 & 1 & 5 & 1 & 5 & 1 & 1 & 1 & 1 & 5 & 1 & 7 & 3 & 1 & - & - & 9 & 5 & 4 & 5 & 3 & 3 & 1 & 5 & 1 \\
\hline 20 & IC-75920 & 1 & 5 & 9 & 1 & 3 & 1 & 3 & 3 & 5 & 1 & 1 & 1 & 1 & 5 & 3 & 7 & 3 & 1 & - & - & 3 & 5 & 1 & 5 & 5 & 3 & 1 & 5 & 1 \\
\hline 21 & IC-216693 & 1 & 5 & 9 & 1 & 3 & 1 & 5 & 1 & 7 & 1 & 1 & 5 & 1 & 7 & 3 & 5 & 2 & 9 & 1 & 3 & 9 & 7 & 1 & 5 & 7 & 4 & 2 & 5 & 1 \\
\hline 22 & IC-216736 & 2 & 7 & 9 & 3 & 3 & 2 & 5 & 1 & 7 & 1 & 5 & 5 & 9 & 7 & 3 & 5 & 5 & 1 & - & - & 9 & 7 & 1 & 5 & 3 & 5 & 4 & 5 & 1 \\
\hline 23 & IC-216689 & 4 & 5 & 9 & 3 & 3 & 2 & 5 & 1 & 5 & 5 & 5 & 5 & 1 & 9 & 1 & 5 & 5 & 1 & - & - & 9 & 7 & 4 & 5 & 3 & 5 & 2 & 5 & 1 \\
\hline 24 & IC-217783 & 1 & 7 & 9 & 1 & 3 & 1 & 3 & 1 & 7 & 1 & 1 & 3 & 1 & 5 & 3 & 5 & 2 & 1 & - & - & 9 & 7 & 4 & 5 & 7 & 4 & 2 & 7 & 1 \\
\hline 25 & IC-217746 & 4 & 5 & 9 & 3 & 3 & 2 & 5 & 1 & 5 & 5 & 5 & 1 & 9 & 7 & 3 & 3 & 3 & 1 & - & - & 3 & 7 & 1 & 5 & 5 & 5 & 5 & 5 & 1 \\
\hline 26 & IC-217747 & 4 & 7 & 9 & 3 & 3 & 2 & 5 & 1 & 3 & 5 & 5 & 3 & 9 & 9 & 5 & 5 & 3 & 1 & - & - & 9 & 7 & 1 & 5 & 5 & 2 & 5 & 5 & 1 \\
\hline 27 & IC-217748 & 4 & 7 & 9 & 3 & 3 & 2 & 5 & 1 & 7 & 7 & 5 & 1 & 1 & 5 & 1 & 3 & 3 & 1 & - & - & 1 & 5 & 4 & 7 & 3 & 5 & 2 & 7 & 1 \\
\hline 28 & IC-217760 & 1 & 5 & 9 & 1 & 3 & 1 & 3 & 3 & 5 & 1 & 1 & 1 & 1 & 5 & 1 & 5 & 2 & 1 & - & - & 9 & 7 & 1 & 5 & 7 & 5 & 2 & 9 & 1 \\
\hline 29 & IC-217771 & 1 & 7 & 9 & 1 & 3 & 1 & 5 & 1 & 5 & 1 & 1 & 3 & 1 & 5 & 3 & 7 & 2 & 1 & - & - & 7 & 7 & 1 & 3 & 7 & 2 & 4 & 9 & 1 \\
\hline 30 & IC-217749 & 4 & 1 & 9 & 3 & 3 & 2 & 5 & 1 & 7 & 7 & 5 & 1 & 9 & 7 & 3 & 5 & 5 & 1 & - & - & 7 & 5 & 4 & 5 & 5 & 3 & 1 & 7 & 1 \\
\hline 31 & IC-217750 & 1 & 7 & 9 & 1 & 3 & 1 & 5 & 1 & 7 & 7 & 1 & 3 & 1 & 5 & 1 & 5 & 2 & 1 & - & - & 7 & 5 & 4 & 5 & 5 & 4 & 2 & 5 & 1 \\
\hline 32 & IC-217758 & 4 & 1 & 9 & 3 & 3 & 2 & 5 & 1 & 5 & 7 & 5 & 1 & 9 & 5 & 3 & 7 & 6 & 1 & - & - & 3 & 5 & 4 & 5 & 3 & 5 & 2 & 5 & 1 \\
\hline 33 & IC-217762 & 4 & 1 & 9 & 3 & 3 & 2 & 5 & 1 & 7 & 7 & 5 & 1 & 9 & 5 & 1 & 7 & 5 & 1 & - & - & 3 & 5 & 4 & 5 & 5 & 4 & 2 & 5 & 1 \\
\hline 34 & IC-217769 & 4 & 5 & 9 & 3 & 3 & 2 & 5 & 3 & 7 & 7 & 5 & 1 & 9 & 5 & 1 & 3 & 2 & 1 & - & - & 1 & 5 & 4 & 5 & 5 & 3 & 2 & 5 & 1 \\
\hline 35 & IC-217776 & 4 & 5 & 9 & 3 & 3 & 2 & 3 & 3 & 5 & 7 & 5 & 1 & 9 & 7 & 1 & 7 & 3 & 1 & - & - & 7 & 5 & 4 & 5 & 7 & 4 & 1 & 5 & 1 \\
\hline
\end{tabular}

a. Basal leaf sheath colour, b. Leaf pubescence of blade surface, c. Leaf auricles, d. Leaf anthocyanin colouration of auricles, e. Leaf shape of ligule, f. Leaf colour of ligule, g. Time of heading (50\% of plants with panicles), h. Flag leaf attitude of blade (early observation), i. Spikelet density of pubescence of lemma, j. Lemma anthocyanin colouration of apex, k. Spikelet colour of stigma, 1. Stem length (excluding panicle; excluding floating rice), m. Stem anthocyanin colouration of nodes, n. Panicle length of main axis, o. Flag leaf attitude of blade (late observation), p. Panicle curvature of main axis, q. Spikelet colour of tip of lemma, r. Panicle awns, s. Panicle colour of awns (late observation), t. Panicle distribution of awns, u. Panicle attitude of branches, v. Panicle exsertion, w. Sterile lemma colour, x. Decorticated grain length, y. Decorticated grain width, z. Decorticated grain shape (in lateral view), aa. Decorticated grain colour, ab. Endosperm content of amylase and ac. Decorticated grain aroma 
All the 35 genotypes have auricles of which 22 have colourless auricles and 13 lines have purple colouration, while coming to the shape of the ligule all the 35 lines have split shape of which 23 lines have green colour ligules while 12 others have purple ones. The time of heading (50\% of plants with panicles) were observed and noticed that 5 genotypes are early, 20 genotypes are medium duration and 10 lines are late duration types. Erect type of flag leaf blade is observed in 30 genotypes and semi-erect in 5 lines.

For density of pubescence of lemma on spikelet 24 lines showed medium, 10 lines with strong and 1 line with very weak pubescence. It is important to note that no cultivar exhibited male sterility. 8 cultivars showed strong coloration 6 lines with medium colouration and remaining were shown absence anthocyanin coloration of area below the apex. For colour of stigma 21 cultivars shown white, 14 were of purple colour. For the stem length (excluding panicle) 25 cultivars were of very short 7 were of short 3 were of medium. 26 cultivars were shown absence for anthocyanin colouration of node and reaming 9 found presence for the character. Panicle lengths for 21 were of medium, 12 were of long but only two was of very long. Flag leaf (attitude of blade) 22 were of erect, 11 were of semi erect and 2 are of horizontal (Table 2).

For the character panicle (curvature of main axis) 20 were of deflexed, 10 were of drooping and 5 were of semi straight. Colour of tip of lemma 17 were of yellowish 10 were brown, 8 lines were of purple colour. For the character sterile lemma colour 22 cultivars were of straw colour 13 with purple colour. 29 cultivars were shown absence of awns and 6 were shown presence of awns appearing mostly at the tips only with yellowish white coloue most commonly. Semi erect to spreading was observed for 15 cultivars 2 were of erect to semi erect but 14 were of spreading type. Mostly that is 23 cultivars were of exerted panicle exertion, 11 were of well exerted type, but only one cultivar is of partly exerted type.

Coming to the characters of decorticated grain 33 lines have medium length with one each in short and long length and 17 lines with narrow grain width, 12 with medium width and 6 were broad types with an overall shape of 3 short bold, 8 medium slender, 6 long slender and 18 long bold, 11 lines with white colour, 17 with light brown 3 with dark brown and 4 red in colour. For amylase content in endosperm 24 were of medium amylase content, 9 with high and 2 were of very high with no aroma for all the 35 genotypes.

Thus, it is concluded that out of 35 landraces of rice, 22 cultivars were found to be distinctive on the basis of 29 essential characters. This study will be useful for breeders, researchers and farmers to identify and choose the restoration and conservation of beneficial genes for crop improvement.

\section{References}

Anonymous, 2001. Protection of Plant Varieties and Farmers Right Act (No. 53 of 2001). Dept. of Agriculture and Cooperation. Ministry of Agriculture, Govt. Of India, krishi Bhawan, New Delhi.

Dutefield, G., 2001. Intellectual Property Right, Trade and Biodiversity: The case of seed and plant varieties. In: Background Study Material for Training on IPR and WTO to NARS Scientists, Vol. I. ICAR, New Delhi.

Patra, B.C., 2000. Collection and characterization of rice genetic resources from Keonjhar district of Orissa. Oryza 34:324-326. 
Raut, V.M., 2003. Qualitative genetics of Soyabean-a review. Soybean Research $1: 1-28$.

Roy, J.K., De RN, Ghorai DP and Panda A. 1985. Collection and Evaluation of Genetic Resources of Rice in India. Phyrtobreedon 1:1-9.

Shobha Rani, N., Shobha Rao LV, Viraktamath BC, Mishra B. 2004. National Guidelines for the Conduct of Tests for Distinctiveness, Uniformity and Stability. Directorate of Rice Research: 6-13.

Siddiq, E. A., 2002. Exploiting means to adapt GM rice. The Hindu Survey of
Indian Agriculture. Kasturi and Sons Ltd., Chennai pp. 47-52.

Singh, Y., and U.S. Singh. 2008. Genetic diversity analysis in aromatic rice germplasm using agro- morphological traits. J. Pl. Genet. Resour. 21(1): 3237.

Song, Q.J., C.V. Quigley, R.L. Nelson, T.E. Carter, H.R. Boerma, J.L. Strachan and P.B. Crega. 1999. A selected set of trinucleotide simple sequence repeat markers for soybean cultivar identification. Plant Var. Seeds, 12: 207 -220 .

\section{How to cite this article:}

Kalyan, B., K.V. Radha Krishna and Subba Rao, L.V. 2017. DUS Characterization for Germplasm of Rice. Int.J.Curr.Microbiol.App.Sci. 6(10): 3480-3487. doi: https://doi.org/10.20546/ijcmas.2017.610.410 